\title{
A Model for Flood Basalt Vulcanism
}

\author{
by $\mathrm{K} \cdot \mathrm{G} \cdot \mathrm{COX}$ \\ Department of Geology and Mineralogy, Parks Road, Oxford, U.K.
}

(Received 15 June 1979; in revised form 19 October 1979)

\begin{abstract}
A B S T R A C T
The question of whether basaltic rocks in continental flood basalt provinces are primary magmas or whether they are descended in general from picritic parent magmas is reviewed. It is suggested that the latter is more likely to be correct on the evidence of phase relations and the relative rareness of mantle materials with appropriate $\mathrm{Fe} / \mathrm{Mg}$ ratios.

Major element variations in the residual liquids of fractional and equilibrium crystallization of basaltic magmas are modelled for a variety of crystallizing assemblages. It is concluded that crystallization of olivine, clinopyroxene, and plagioclase has a marked effect on buffering chemical change in many important elements. It is this effect which accounts for the apparent uniformity of large volumes of flood basalts, not, as has sometimes been supposed, a series of implausible coincidences in the amount of material fractionated from each magma batch. It is further argued that much of the variation seen in basalts may be imposed by polybaric fractionation operating throughout crustal depths, that is at pressures up to at least $12 \mathrm{~kb}$. Parental picritic magmas rising from the mantle reach the surface in exceptional areas of crustal thinning. More usually, however, it is suggested that they intrude the base of the crust as a series of sills which differentiate into upper gabbroic and lower ultramafic portions. Much of the 'low pressure' fractionation of basaltic magmas may take place in this deep crustal sill complex and evolved liquids are transmitted to the surface as their density becomes sufficiently low. This implies that in areas of flood vulcanism a potentially large new contribution to the crust is made by underplating, the volumes of concealed cumulates being at least as large as the amount of erupted surface lava.
\end{abstract}

\section{INTRODUCTION}

THE comparatively uniform and voluminous continental flood basalt sequences of the great Mesozoic-Tertiary provinces (Columbia River, North Atlantic, Deccan, Paraná, Karroo, Antarctica, and Siberian Platform) pose a substantial problem with regard to the nature of their parental magmas. Are these essentially basaltic, so that much of the surface lava represents primary or near-primary magma, or are the parental magmas more magnesian (picritic), so that the surface lavas are largely derivative and non-primary? A closely similar problem is raised for the largely alkaline flood basalts of Ethiopia and Kenya as well as for midocean ridge basalts. The general topic has been the subject of considerable debate for both the oceanic and continental environments (O'Hara, 1965, 1968a; Wilkinson \& Binns, 1977; Hart \& Davis, 1978). This paper considers evidence from continental provinces, particularly from southern Africa, and concludes that the picritic-parent hypothesis is strongly favoured by the evidence at present available. This conclusion has far-reaching consequences for the nature of flood basalt vulcanism in general and for crustal evolution in regions affected by such episodes. 


\section{PARENTAL PICRITE vs. PARENTAL BASALT}

In the rather well-matched and evenly-balanced debate which has taken place so far it is tempting to discern that the views of various authors are coloured by the flood basalt provinces they have been most concerned with or influenced by. Two provinces in particular are notable for the amounts of picritic lava actually erupted (West Greenland-Baffin Island, Lebombo Monocline area of Karroo) and it is demonstrable that at least some of this material reached the earth's surface in a completely or very-largely liquid condition. Given the availability of picritic liquids, at least at times within these provinces, it is not surprising that some authors have argued that basaltic magmas are derived from them (e.g. Clarke, 1970; Cox, 1972). On the other hand some provinces such as the Columbia River, Paraná, East Greenland and Deccan, although picritic rocks are erupted locally in some of them, are strongly dominated by basalts. Viewed from these provinces the ordinary basaltic rocks inevitably come forward as the more obvious candidates for primary status. There are however two commonly raised objections to this latter conclusion. Firstly, the magnesium-iron ratios of the erupted basaltic lavas are generally too low to have been in equilibrium with what appears to be the dominating olivine composition of the upper mantle. Secondly, because of the comparatively low heat flow in continental areas it is difficult to visualize substantial melting of the mantle except at considerable depths. Known phase relations of natural rocks (e.g. O'Hara, 1968b) suggest that even initial melts of peridotitic source rocks are likely to be picritic at the appropriate depths.

To illustrate the first point the recent compilation of Gurney \& Harte (in press) distinguishes four categories of peridotite nodules from southern African kimberlites. Their assessment of abundances of the types and of characteristic olivine compositions is given in Table 1. Roman numerals refer to the Gurney \& Harte categories. Their categories III (dunites) and VI (harzburgites with high- $\mathrm{Al}_{2} \mathrm{O}_{3}$ orthopyroxene) have been omitted since dunites are unlikely to be the common residua of basaltic melting, and no detailed study has been made of Type VI.

\section{T A B LE 1}

Olivine composition ranges and abundances of various peridotite types in southern African kimberlites (after Gurney \& Harte (in press, table 1))

\begin{tabular}{lll}
\hline \multicolumn{1}{c}{ Type } & \multicolumn{1}{c}{ Abundance } & \multicolumn{1}{c}{$\begin{array}{c}\text { Olivine compositional } \\
\text { range }\end{array}$} \\
\hline I. Common coarse peridotites & $\begin{array}{c}\text { Universal distribution and } \\
\text { abundant } \\
\text { Widespread but usually rare }\end{array}$ & $\mathrm{Fo}_{\mathbf{9 1 - 9 9}}$ \\
$\begin{array}{l}\text { II. Pyroxenites and peridotites with } \\
\text { high } \mathrm{FeO} / \mathrm{MgO}\end{array}$ & $\mathrm{Fo}_{\mathbf{8 3 - s 9}}$ \\
$\begin{array}{l}\text { IV. Deformed peridotites with calcic } \\
\text { Cpx }\end{array}$ & Widespread and common & Indistinguishable from Type I \\
$\begin{array}{l}\text { V. Deformed peridotites with sub- } \\
\text { calcic } \mathrm{Cpx}\end{array}$ & $\begin{array}{c}\text { Abundance highly variable. } \\
\text { Common in some pipes, absent } \\
\text { in others }\end{array}$ & $\mathrm{Fo}_{\mathbf{m - 9 2}}$ \\
\hline
\end{tabular}


In Fig. 1 the magnesium-iron ratios of liquids expected to be in equilibrium with the different peridotite categories according to the Roeder \& Emslie (1970) distribution coefficient criterion are compared with ratios for Karroo basalts erupted in southern Africa. The figure demonstrates that there is no difficulty, at least in terms of magnesium-iron relationships, in visualizing the picritic rocks of the Karroo province as primary melts. There is a substantial overlap between the $m g$ values of the various peridotite types and the $\mathrm{M}^{\prime}$ values for the erupted lavas. However, for the ordinary basaltic rocks of the province only the relatively basic Lesotho lavas show $\mathbf{M}^{\prime}$ values which overlap with the $m g$ values of the peridotites, and then only with Type II which is usually of rare occurrence. So far, and it must be emphasized that the Gurney \& Harte compilation is based on a

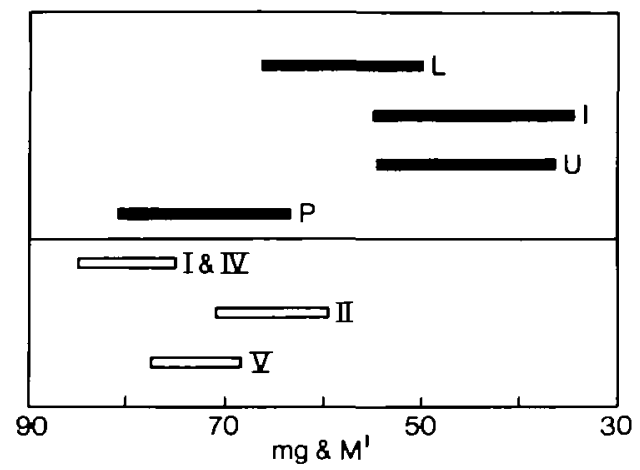

FIG. 1. Comparison of magnesium-iron ratio ranges of southern African peridotites (open bars) and Karroo lavas (flled bars). Roman numerals are peridotite categories of Gurney \& Harte (in press). Lavas are $P=$ picrite basalts, Nuanetsi (data from Cox \& Jamieson, 1974); $U$ = upper basalts of Nuanetsi; I = interbedded basalts of Nuanetsi (unpublished data); $L=$ Lesotho basalts (data from Cox \& Hornung, 1966). A general account of the Nuanetsi lavas is given by Cox et al. (1965). Peridotites are plotted against $m g$ values where $m g=100 \mathrm{Mg} / \mathrm{Mg}+\mathrm{Fe}^{2+}$ (atomic). Ranges shown for lavas are $\mathbf{M}^{\prime}$ values where $\mathbf{M}^{\prime}=$ $100 \mathrm{Mg} / \mathrm{Mg}+0.85\left(\mathrm{Fe}^{2+}+\mathrm{Fe}^{3+}\right)$ i.e. assuming that 15 per cent of $\mathrm{Fe}$ is oxidized in whole-rock analyses (see Wilkinson \& Binns, 1977 for discussion of definition of $m g$ and $\mathbf{M}$ ).

very large amount of data, there is thus no evidence of the existence of any significant amount of mantle beneath southern Africa which has a composition suitable for the production of lavas of the Nuanetsi upper basalt and interbedded basalt type, nor for the more evolved members of the Lesotho sequence. The general problem has been thoroughly discussed by Wilkinson \& Binns (1977) who prefer to emphasize the presence of iron-rich lherzolites within the upper mantle and postulate that even rather iron-rich lavas (so called anorogenic tholeiitic andesites) similar to the more evolved type discussed above can be generated as primary melts. Clearly this is a possibility but if accepted it would imply that southern African kimberlites consistently fail to sample the mantle involved in much of the Karroo basalt magmatism. The present writer's preference is however to interpret the evidence as pointing to the primary nature of the picritic liquids and the distinctly derivative nature of the ordinary basaltic rocks particularly those showing $M^{\prime}$ values below 60 .

The second objection is more difficult to counter if the source regions of basalts are relatively dry for it is difficult to dispute the contraction of the olivine plus liquid stability field with increasing pressure, a factor which must inevitably lead 
to the production of melts more magnesian than typical flood basalts. The recent suggestion of Presnall et al. (1979) who argue that the characteristics of sea floor basalts are consistent with a primary origin at $9 \mathrm{~kb}$, is hardly relevant to the continental environment where such pressures would be more appropriate to the lower crust than the mantle. Furthermore, high pressure experimental work on water-bearing basic and ultrabasic rock systems has on the whole not been conspicuously successful in producing melts analogous to ordinary basalts in composition, the characteristic of many such melts being their high silica contents (e.g. Kushiro, 1972; Green, 1973; Nicholls \& Ringwood, 1973; Mysen \& Boettcher, 1975).

To summarize, the evidence of phase relations, and the evidence available for the composition of the upper mantle, taken at face value, would appear to support the idea that primary mantle melts are likely to be picritic, and as a consequence most of the observed flood basalt sequences must therefore be derivative. What factor is it then which makes so many workers in this field resistant to the idea? It appears most likely to the present writer that the sheer volume and particularly the allegedly uniform nature of the erupted products are the features which do not appear to be explained by the primary picrite hypothesis, and therefore encourage the view that the surface basalts are primary.

Large volumes of uniform liquid are traditionally produced in petrogenetic hypotheses by partial melting or fractional crystallization involving pseudounivariant equilibria. The earliest important example of this philosophy is provided by Tuttle \& Bowen (1958) working on the granite minimum. The recent hypothesis of Presnall et al. (1979) which suggests that basalts are generated at a pseudounivariant point formed by the transition from plagioclase to spinel peridotite is another excellent example. Liquids produced under pseudo-univariant conditions are supposedly constrained into a limited compositional range and thus contrast with liquids in equilibrium with smaller numbers of phases. An extreme example of the latter would be afforded by basaltic liquids in equilibrium only with olivine. Small amounts of fractionation, either by crystallization or further melting, would produce relatively large changes in liquid composition. Thus the eruption of a large amount of uniform liquid of this type would involve the postulation of an exceedingly restricted temperature range or fractionation stage. This is probably the crux of the argument. If basalts are derived from picritic precursors then they are not the types of liquids produced in pseudo-univariant equilibria, they are merely liquids somewhere along the down-temperature fractionation path and, as such, implausible conditions have to be postulated to account for their great volume and their comparative uniformity. Carmichael et al. (1974) for example, in criticizing the general position of $\mathrm{O}^{\prime} \mathrm{Hara}$, comment that the picritic parent hypothesis appears to demand that each successive magma batch must crystallize (and lose) exactly the same amount of olivine during ascent. This they not unnaturally regard as improbable.

Viewed in these terms the Carmichael et al. argument appears to be a powerful criticism of the primary picrite hypothesis but it does not take account of one highly important factor. The typical flood basalt is not erupted carrying pheno- 
crysts of olivine only. Most flood basalts are more or less porphyritic though in some sequences phenocryst contents may be very low. Plagioclase phenocrysts are almost invariably present and are accompanied either by olivine or by clinopyroxene or by both. This indicates beyond any reasonable doubt that the liquids concerned have been involved in relatively low-pressure equilibration with phases other than olivine. The Carmichael et al. criticism thus requires the more detailed evaluation given in the next section.

\section{THE 'LOW PRESSURE' REGIME OF BASALT FRACTIONATION}

The term 'low pressure' has been used in studies of basalt petrology with a variety of meanings but often with the implication of approximation to 1 atmosphere. However, basalts may in principle have crystallized plagioclase at any crustal depth, that is to say in a pressure regime of up to $10-15 \mathrm{~kb}$. Thus the fractionation of dry basaltic magmas over this quite large range leads to residual liquids with a certain commonness of character. Phase relations may change quite substantially (e.g. Presnall et al., 1979) but the phases available for fractionation remain essentially the same. Careful examination of data and favourable geological circumstances may be necessary before it is possible to detect the rather subtle differences between fractionation at say $10 \mathrm{~kb}$ as opposed to 1 atmosphere. It is the contention of the present work that much of the variation seen in basalts and normally ascribed to the operation of 'low pressure' fractionation processes is likely to be the result of a complex sequence of polybaric events within the entire pressure range of up to perhaps $15 \mathrm{~kb}$. To find evidence of this, the favourable geological circumstances referred to above must involve the eruption of basaltic sequences in which fractionation processes at one pressure are dominant, but those at another pressure are still detectable. Sequences in which advanced fractionation has taken place at more than one pressure are likely to produce compositional data so scattered as to defy interpretation.

Two flood basalt sequences and one dyke swarm have been selected for consideration in the present study; these are:

(1) the basalts of the Paraná province in South America. Large numbers of analyses are provided by Rüegg (1976) and all those designated as basalt (as opposed to diabase) and having $\mathrm{SiO}_{2}$ contents of less than 55 per cent have been included.

(2) the Lesotho basalts of the Karroo province of southern Africa (data from Cox \& Hornung, 1966). This large outlier is made up of amongst the most monotonously uniform lavas within the province.

(3) the dolerites of the Rooi Rand dyke swarm of the Karroo province (data from Armstrong, 1978, and J. W. Bristow, pers. comm.). This suite is included because it provides a somewhat more clearly defined fractionation trend than any other group of basic rocks within the province.

Some important major element variations are shown in Figs. 2-4. Variation in $\mathrm{SiO}_{2}$ is not shown in the diagrams but is relatively small as in any typical basaltic suite. The most basic rocks illustrated can properly be termed tholeiitic basalts 


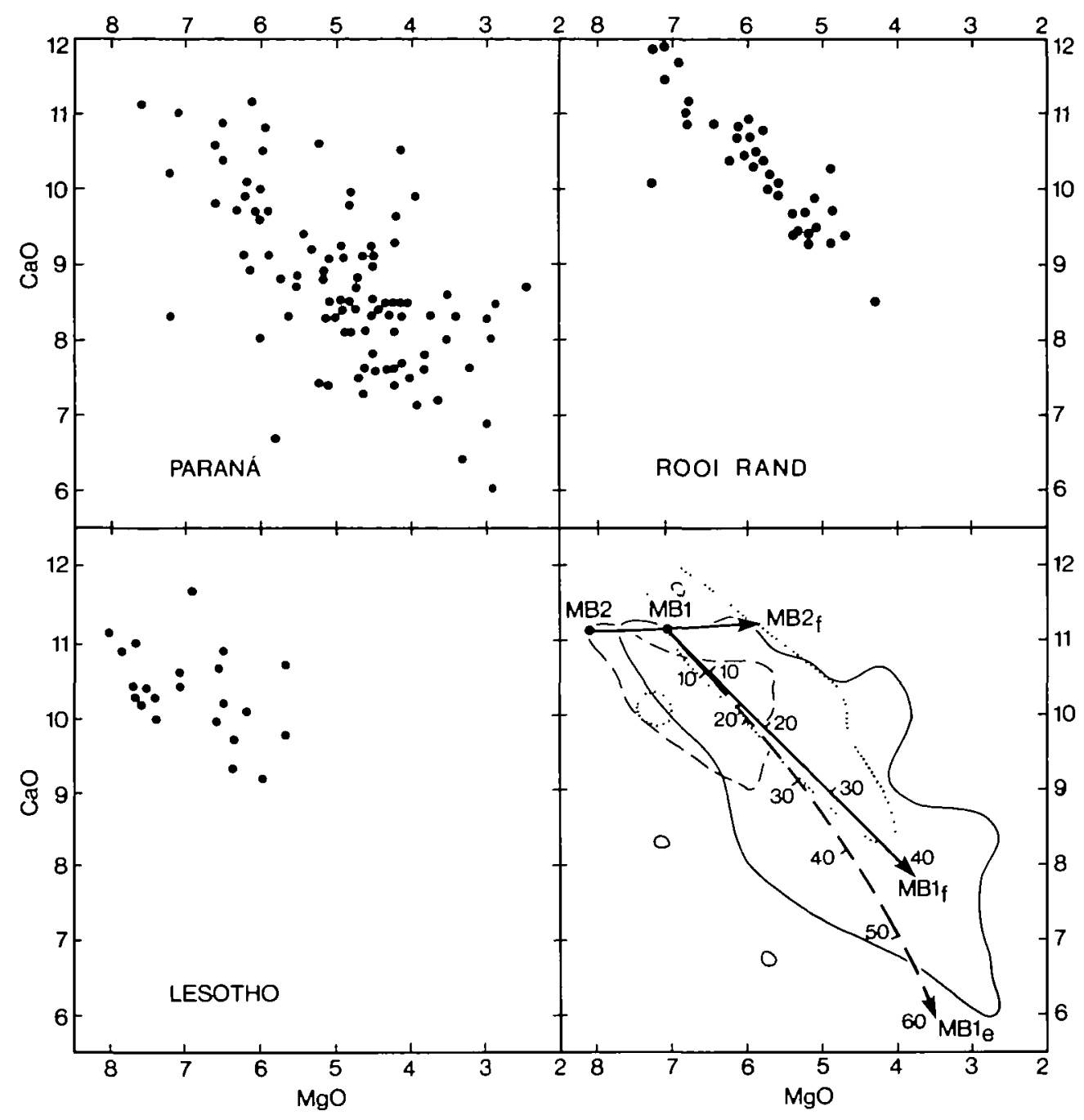

FIG. 2. $\mathrm{CaO}$ us. $\mathrm{MgO}$ variation diagrams for whole rock compositions of Paraná, Rooi Rand dolerites and Lesotho lavas. Lower right diagram shows the same fields in outline (Parana $=$ solid line, Rooi Rand = dotted line, Lesotho = dashed line). Solid arrows show liquid paths of fractional crystallization of MB1 by crystallization of olivine-clinopyroxene-plagioclase to give $M B 1_{f}$, and of $M B 2$ by olivine-plagioclase crystallization to give $\mathrm{MB2}$. Broken arrow shows path of residual liquid of equilibrium crystallization of $\mathrm{MB} 1$ leading to $\mathrm{MB} 1$, as olivine-clinopyroxene-plagioclase crystallizes. Numbers on arrows indicate amounts of solid material crystallized as a percentage of the original liquid weight.

though for the more evolved types tholeiitic andesite is a more appropriate term (e.g. see Wilkinson \& Binns, 1977). The obvious major element characteristics of the suites are the sympathetic behaviour of $\mathrm{CaO}$ and $\mathrm{MgO}$, the relatively constant though scattered $\mathrm{Al}_{2} \mathrm{O}_{3}$, relatively constant $\mathrm{SiO}_{2}$, and a tendency towards strong $\mathrm{Fe}$ enrichment relative to $\mathrm{Mg}$. The trends illustrated are very familiar, and are almost certainly generated largely by the fractional crystallization of olivine, clinopyroxene, and plagioclase. The present study attempts to quantify the above statement and in particular to determine the actual amounts of crystal removal which are required by the data. 


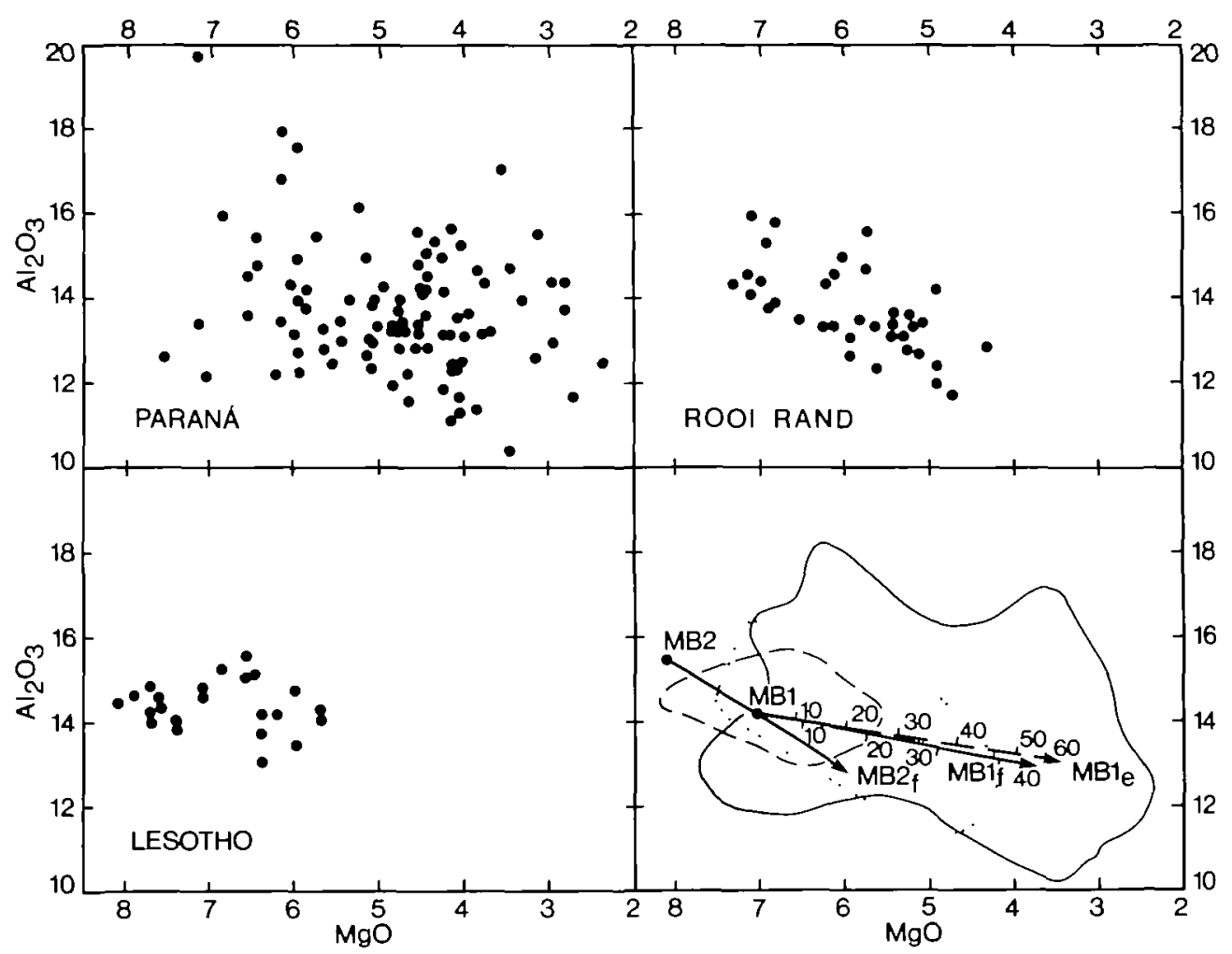

Fro. 3. $\mathrm{Al}_{2} \mathrm{O}_{3}$ vs. $\mathrm{MgO}$ variation diagrams. Symbols as in Fig. 1 .

\section{Numerical modelling methods}

The numerical modelling of major element fractionation trends for basaltic rocks depends critically on the compositions of the phases assumed to crystallize. Phenocryst analyses may be used but suffer from the disadvantage that zoning often makes it difficult or impossible to decide on appropriate mineral compositions though some very successful modelling has been carried out in specific cases (e.g. Wood, 1978; Richardson, 1979). In the present generalized study the major element distribution coefficients of Nathan \& Van Kirk (1978) have been used to determine the compositions of phases equilibrating with given liquids. The principal defect of this procedure lies in the simplified clinopyroxene compositions used since these are expressed only as diopside-hedenbergite-acmite solid solutions without any orthopyroxene components. In the present study the very small acmite component has also been omitted. Nevertheless the advantage of the method is that it enables residual liquid paths to be calculated for both equilibrium and fractional crystallization and gives, within the limitations imposed by the simplified mineral compositions and distribution coefficients, accurate values for $F$, the fraction of liquid remaining. The difficulties involved in trying to derive accurate $F$ values alternatively by the use of mixing calculations are discussed in some detail by Wood (1978). It must be stressed that in the present work it has been desired to avoid completely the use of incompatible trace elements for 


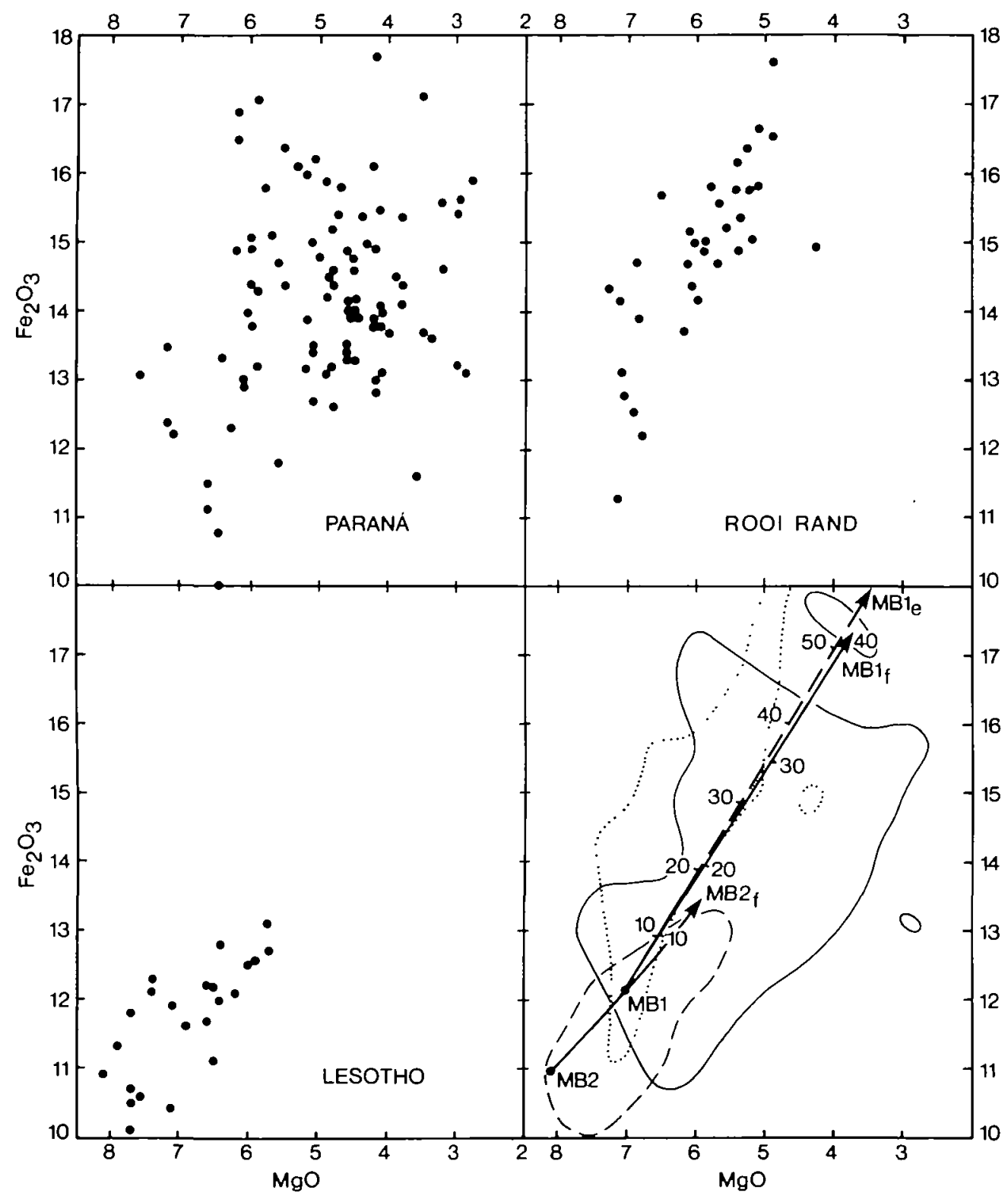

Fig. 4. Total $\mathrm{Fe}$ as $\mathrm{Fe}_{2} \mathrm{O}_{3}$ vs. $\mathrm{MgO}$ variation diagrams. Symbols as in Fig. 2.

this purpose, since their concentrations may be influenced by additional factors such as repeated magmatic mixing (cf. O'Hara, 1977).

In the present study the Nathan and Van Kirk program to determine evolutionary paths of fractionating liquids at 1 -atmosphere has not been used. Instead, mineral proportions in a variety of model fractionating assemblages have been selected at will. This allows the investigation of alternative models and does not restrict the study to the 1-atmosphere environment. Details of the calculations are given in the Appendix. 
The main part of the quantitative study has been carried out on a composition termed Model Basalt 1 (MB1) (see Table 2). This is an arbitrary composition selected to conform approximately with the basic liquids of all three sets of analytical data. Liquid evolution paths have been calculated for both fractional and equilibrium crystallization in which it is assumed that olivine, clinopyroxene and plagioclase separate in the proportions 15:35:50 (see trends in lower right corners of Figs. 2-4 leading to points $M B 1_{f}$ and $M B 1_{e}$ ). The phase proportions used are to a certain extent arbitrary but have been found by trial and error to give a reasonable fit to the analytical data. However, they are a plausible expression of likely proportions in the natural system at low pressures. The phase diagram for natural basalts given by Cox et al. (1979) for example, suggests that at 1 atmosphere pressure tholeiitic liquids crystallize olivine, clinopyroxene and plagioclase in the approximate proportions 16:27:57. However, separation of such high proportions of plagioclase leads to $\mathrm{Al}_{2} \mathrm{O}_{3}$ depletion which seems too strong to match the natural data. The relatively low density of plagioclase is assumed to inhibit its settling tendency relative to olivine and clinopyroxene (see Bottinga \&

T A B LE 2

Compositions, fractions of liquid remaining, and equilibrium mineral compositions of model basaltic liquids and their derivatives

\begin{tabular}{|c|c|c|c|c|c|c|c|}
\hline & $M P$ & $M B 1$ & $M B I_{f}$ & $M B 1_{e}$ & $M B 2$ & $M B 2$ & $M B 3$ \\
\hline $\mathrm{SiO}_{2}$ & $48 \cdot 14$ & 50.76 & $51 \cdot 14$ & 50.60 & 50.17 & 51.43 & 50.62 \\
\hline $\mathrm{TiO}_{2}$ & 1.49 & 2.03 & 3.39 & 4.86 & 1.75 & 2.37 & 1.75 \\
\hline $\mathrm{Al}_{2} \mathrm{O}_{3}$ & 10.46 & 14.21 & 13.05 & 13.06 & 15.40 & 12.82 & 14.51 \\
\hline $\mathrm{Fe}_{2} \mathrm{O}_{3}$ & 1.91 & 2.59 & 4.32 & 6.20 & 2.24 & 3.02 & 2.24 \\
\hline $\mathrm{FeO}$ & 9.20 & 8.63 & 11.70 & 10.66 & 7.94 & 9.39 & 7.83 \\
\hline $\mathrm{MgO}$ & 18.00 & $7 \cdot 11$ & 3.82 & 3.49 & 8.08 & 5.99 & 7.91 \\
\hline $\mathrm{CaO}$ & 8.22 & $11 \cdot 17$ & $7 \cdot 85$ & 5.92 & $11 \cdot 13$ & 11.25 & 11.93 \\
\hline $\mathrm{Na}_{3} \mathrm{O}$ & 1.68 & 2.28 & 2.70 & $2 \cdot 30$ & 2.22 & 2.33 & $2 \cdot 16$ \\
\hline $\mathrm{K}_{2} \mathrm{O}$ & 0.75 & 1.02 & 1.70 & 2.44 & 0.88 & 1.19 & 0.88 \\
\hline $\mathrm{P}_{2} \mathrm{O}_{3}$ & 0.15 & 0.20 & 0.33 & 0.48 & 0.17 & 0.23 & 0.17 \\
\hline$F_{M P}$ & 1.000 & 0.736 & 0.441 & 0.308 & & & \\
\hline$F_{M B 1}$ & 1.358 & 1.000 & 0.599 & 0.418 & 1.158 & 0.857 & 1.158 \\
\hline$F_{M B 2}$ & & 0.864 & & & 1.000 & 0.740 & \\
\hline$F_{M B 3}$ & & 0.864 & & & & & 1.000 \\
\hline $\begin{array}{l}\mathrm{OI} \\
\mathrm{Pl}\end{array}$ & $\mathrm{Fo}_{92.2}$ & $\begin{array}{l}\mathrm{Fo}_{33 \cdot 2} \\
\mathrm{An}_{3}\end{array}$ & $\begin{array}{l}\mathrm{Fo}_{66 \cdot 2} \\
\mathrm{An}\end{array}$ & $\begin{array}{l}\mathrm{Fo}_{66 \cdot 2} \\
\mathrm{An}^{2}\end{array}$ & $\begin{array}{l}\mathrm{Fo}_{85.9} \\
\mathrm{An}_{71.7}\end{array}$ & $\begin{array}{l}\mathrm{Fo}_{79} \\
\mathrm{An}_{743}\end{array}$ & $\begin{array}{l}\mathrm{Fo}_{15.1} \\
\mathrm{An}^{2}\end{array}$ \\
\hline Cpx & - & $\mathrm{Di}_{39.1}$ & $\mathrm{Di}_{16.3}$ & $\mathrm{Di}_{76.5}$ & - & - & $\mathrm{Di}_{91,0}$ \\
\hline
\end{tabular}

MP = model picrite; derived by fractional addition of olivine to MB 1 .

MB1 = moded basalt 1 .

$M B 1_{f}=$ residual liquid formed by fractional crystallization of MB1. Phases removed are olivine, clinopyroxene and plagioclase in constant weight ratio of 0.15:0.35:0.50. Each increment extracted is 5 per cent of the weight of the remaining liquid.

$M B 1_{e}=$ residual liquid formed by equilibrium crystallization of MB1. Phases crystallized are as for $M B 1_{r}$

$\mathrm{MB}^{\mathrm{e}}=$ model basalt 2; derived by fractional addition of olivine and plagioclase in weight ratio 0.30:0.70 to $\mathrm{MB} 1$. Increments are 5 per cent of liquid weight.

$\mathrm{MB2} 2_{\mathrm{f}}=$ residual liquid formed by fractional crystallization of olivine and plagioclase (weight ratio as for MB2) from MB2. MB1 lies on the fractionation path.

MB3 = Model basalt 3; derived by fractional addition of olivine, clinopyroxene and plagioclase (weight ratios as for $\mathrm{MBI}_{f}$ ) to $\mathrm{MB}$ l. $\mathrm{MBl}$ and $\mathrm{MBl}_{\mathrm{f}}$ lie on the fractionation path derived from this liquid.

$F$ numbers shown are fraction of liquid remaining after partial crystallization of the designated parent liquid. Mineral compositions are equilibrium phases for each liquid calculated from distribution coefficients of Nathan \& Van Kirk (1978, table 9). The acmite component of the clinopyroxene is omitted from consideration. 
Weill, 1970) so that effectively it is removed in less than the cotectic proportions. Hence in the present model the plagioclase amount is reduced arbitrarily to 50 per cent. Similarly, increasing the clinopyroxene/olivine ratio over that required by the phase diagram appears to lead to an improved modelling of $\mathrm{CaO} / \mathrm{MgO}$ relations. As will be argued later some of the fractionation of the suites under study may have taken place at pressures substantially above 1 atmosphere, in the presence of an enlarged primary phase field for clinopyroxene, thus implying a change in the cotectic proportions. The proportions of the three phases selected retain an arbitrary element but fit broadly with petrographic observations that basaltic rocks containing all three phases as phenocrysts usually show an overall excess of plagioclase and substantially more clinopyroxene than olivine.

Equilibrium crystallization of the three phases can be calculated almost exactly (see Appendix) and gives accurate values for $F$ (the fraction of liquid remaining at any stage). Fractional crystallization must however be modelled by repeated extraction of finite increments of the calculated equilibrium phases and is thus sensitive to the step-size used. In the present case all fractionation paths have been calculated by removing (or in some cases adding) a total amount of solid phases equal to 5 per cent of the liquid weight. Trials show that smaller step-sizes lead to only trivial differences in liquid paths when expressed on two-oxide plots, but $\mathrm{F}$ numbers are underestimated by an unknown amount. However, for a given degree of crystallization the equilibrium calculation minimizes the amount of compositional change that takes place. Conversely, underestimating $F$ in the fractionation calculations leads to an exaggeration of the degree of compositional change. Thus for a given composition of residual liquid the $F$ numbers derived by comparison of the equilibrium and fractional curves with the natural data may bracket the actual $F$ number of the natural system. In nature the real evolutionary path must in any case lie between the two extremes since infinitesimally small crystals cannot be separated instantly from their parent liquids.

\section{Comparison of model results with data for natural suites}

The figures (2-4) show that in a broad sense the compositional variation of basalts in the three provinces can be satisfactorily modelled by the fractionation of olivine, clinopyroxene, and plagioclase, and that starting with a liquid containing about 7 per cent $\mathrm{MgO}$ crystallization of $c a .50$ per cent of the original liquid is required to produce the extreme low-MgO rocks of the Parana suite, a slightly lower amount of crystallization being required to form the Rooi Rand range of liquids.

The Lesotho rocks are more basic and show less fractionation than the other two suites, but although the data are scattered there is an indication that the fractionation trends are similar. In order to model these rocks more satisfactorily, MB3 (Table 2) has been generated by the fractional addition of olivine, clinopyroxene and plagioclase to $\mathrm{MB1}$ and has an $\mathrm{MgO}$ content of 7.91. The most evolved Lesotho rocks correspond with $c a$. 20 per cent crystallization of MB1 and this can readily be calculated as representing about 31 per cent crystallization of MB3. 
The first important point about flood basalts can be made at this stage. These rocks may look monotonous and uniform but rather a lot of fractional crystallization of the most basic magma observed is required, even for a restricted suite like Lesotho, to produce the range of liquid compositions erupted. Secondly it is clear that these rocks have undergone substantial fractionation involving plagioclase, that is somewhere within the 'low pressure' regime.

In Fig. 5 liquid compositions are plotted against $F$ number for the fractionation of MB 1 by removal of olivine-clinopyroxene-plagioclase. For purposes of contrast the left hand side of the figure shows how MB1 can be produced by olivine fractionation from a picrite basalt MP (see Table 2) having 18 per cent $\mathrm{MgO}$. Supposing MP to be a parental picritic magma then crystallization of anything from 26.4 weight per cent (giving MB1) to about 63 per cent will give residual liquids within the compositional range of the rocks studied (accepting the figure of 50 per cent of crystallization of MB 1 derived previously). A slightly different picrite, also with 18 per cent $\mathrm{MgO}$, can be generated from $\mathrm{MB} 3$ and indicates that crystallization of from 23 to 54 per cent is permissible while still keeping residual liquids within the more restricted range of the Lesotho lavas.

The figure of 18 per cent $\mathrm{MgO}$ has been chosen to coincide with the $\mathrm{MgO}$ contents of the most basic lavas erupted in the Nuanetsi area in an apparently liquid condition (Cox \& Jamieson, 1974). More basic parental liquids may have existed and if so the estimates given above of total ranges of permissible crystallization would require some reduction. Nevertheless even with this uncertainty there is a strong presumption that apparently uniform flood basalt sequences can be erupted even when there are quite marked fluctuations in the amount of crystal removal from time to time. The reason for this is of course that the fractionation process involved is not just olivine removal (as assumed by Carmichael et al., 1974) but also involves plagioclase and clinopyroxene. The separation of all three phases has a very marked 'buffering' effect on $\mathrm{SiO}_{2}$ and $\mathrm{Al}_{2} \mathrm{O}_{3}$ (see Fig. 5) and strongly reduces the rate at which $\mathrm{MgO}$ is depleted. Only $\mathrm{FeO}$ shows accelerated evolution as the olivine-clinopyroxene-plagioclase assemblage is fractionated, and even this may be strongly damped if an $\mathrm{Fe}-\mathrm{Ti}$ oxide begins to crystallize.

These arguments suggest that flood basalts may be more plausibly derived from picritic parental liquids than previously supposed. Their uniformity is more apparent than real, and in some areas at least, wide variations in the amount of fractionation en route to the surface are evidently permissible.

\section{Evidence of possible polybaric processes}

The argument so far focuses attention on the importance of the low pressure regime in basaltic fractionation but has not been concerned with polybaric processes within it. Amongst the suites discussed both the Lesotho and the Rooi Rand rocks however provide excellent evidence of the operation of polybaric processes. In so far as it is possible to analyse variation within a limited compositional range the Lesotho magmas evidently evolved by the fractionation of olivine, clinopyroxene and plagioclase. However, clinopyroxene phenocrysts are not observed in these rocks. Microphenocrysts of olivine and plagioclase are 

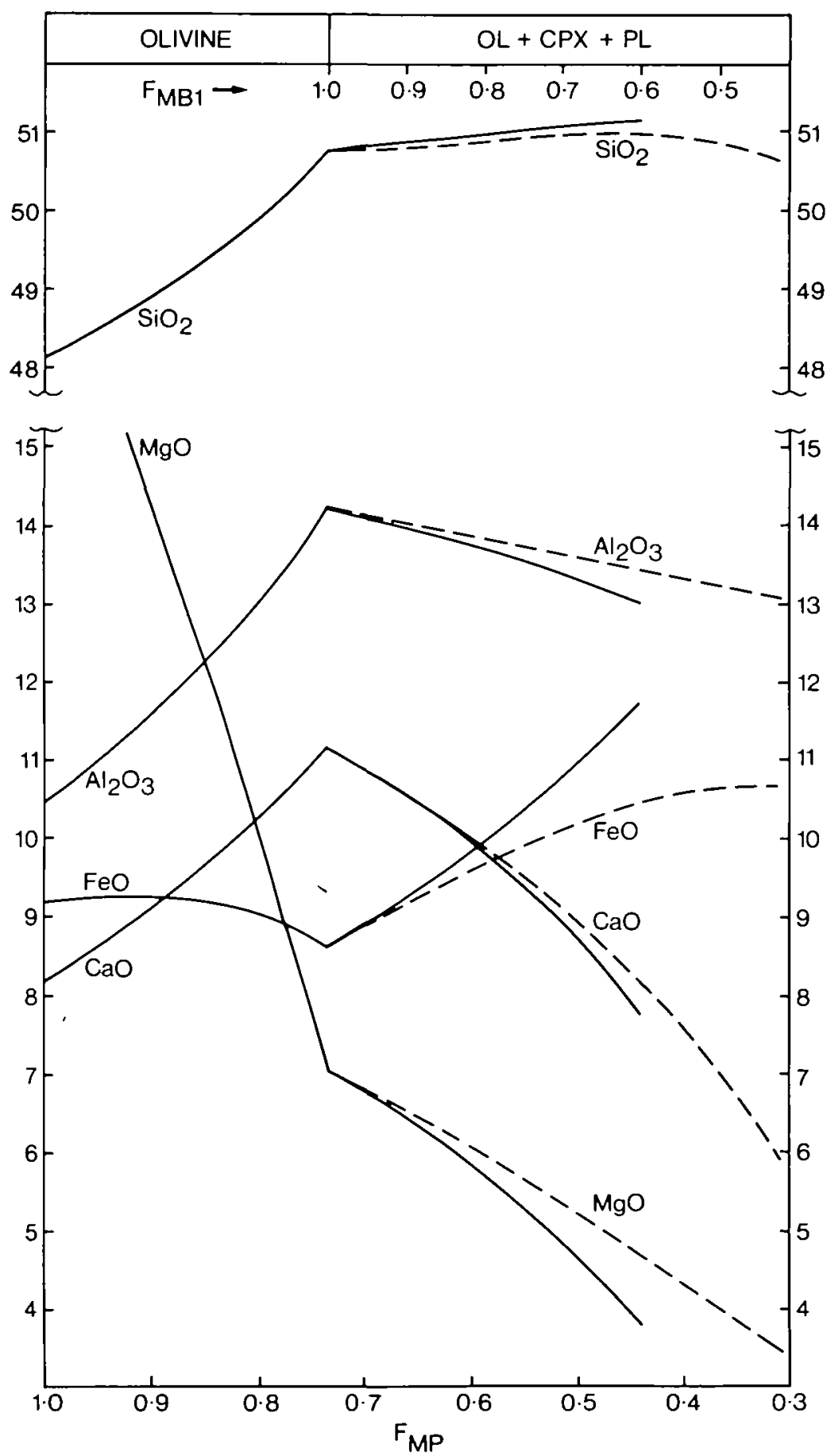

FIG. 5. Evolution of various oxides in residual liquids as a function of the fraction of liquid remaining ( $F$ number). Left hand side shows olivine fractionation from model picrite parent MB using equation 11 of Pearce (1978). Right hand side of diagram shows fractional crystallization (solid curves) and equilibrium crystallization (broken curves) paths of residual liquid evolution as olivine-clinopyroxene-plagioclase crystallizes from model basalt (MB1) in proportions 15:35:50. Lower horizontal scale shows $F$ as a fraction of original picrite weight, upper scale as a fraction of original weight of basalt MBI. 
relatively common and are especially clearly observed in chilled flow-bases. Clinopyroxene in contrast always displays a sub-ophitic texture in the groundmass (Cox \& Hornung, 1966). The implication of the petrography is clearly that the liquids which reached the surface were not saturated with regard to clinopyroxene. At 1 atmosphere pressure the only plausible crystal fractionation mechanism would involve olivine and plagioclase but no clinopyroxene. This has been modelled quantitatively by considering the fractional crystallization of MB2 (see Table 2 and Figs. 2-4), a basalt generated from MB1 by the fractional addition of olivine and plagioclase in the proportions of 30:70. Fractionation of MB2 leads to MB2 via MB1. However, these trends do not fit the natural data particularly well. Nor is this a consequence of the choice of olivine-plagioclase proportions. Increasing the olivine proportion reduces the unacceptable degree of $\mathrm{Al}_{2} \mathrm{O}_{3}$ depletion but leads to an even more unacceptable degree of $\mathrm{CaO}$ enrichment. Conversely, reducing the amount of olivine improves the $\mathrm{CaO} / \mathrm{MgO}$ relations while making the behaviour of $\mathrm{Al}_{2} \mathrm{O}_{3}$ worse still. The involvement of clinopyroxene in the fractionation mechanism, despite its absence as a phenocryst, seems inevitably required by the major element data. As an additional exercise the contents of $\mathrm{Cr}$ have been modelled in Fig. 6 using the equation for Rayleigh fractionation and $F$ numbers derived from the major element calculations. Postulation of an initial $\mathrm{Cr}$ content of 470 p.p.m. for MB3 leads to quite a good fit with the data apart from two high-Cr points. Even in crude terms the evidence of $\mathrm{Cr}$ depletion as $\mathrm{MgO}$ falls is obviously consistent with the presence of clino-

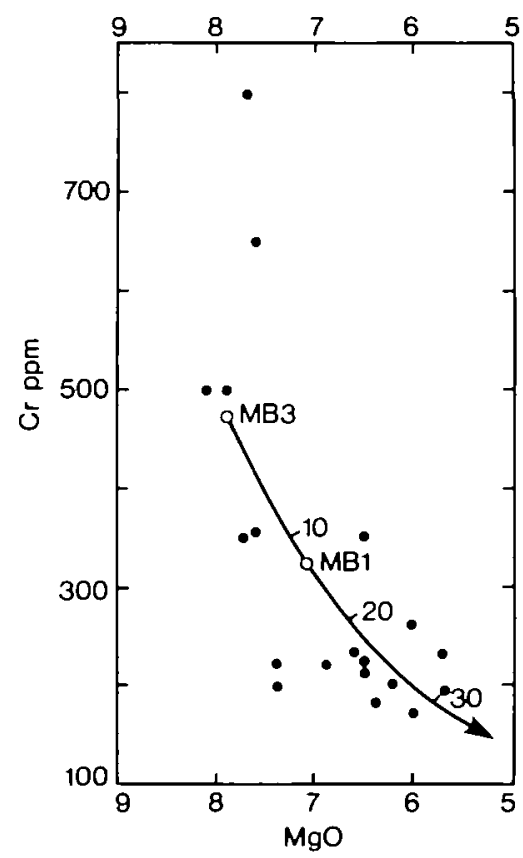

FIG. 6. $\mathrm{Cr}$ us. MgO variation diagram for Lesotho basalts. Arrow shows path of residual liquid of fractional crystallization of $\mathrm{MB3}$ as olivine-clinopyroxene-plagioclase crystallizes in the proportions 15:35:50. Distribution coefficients assumed are: olivine $=0.2$; clinopyroxene $=10$; plagioclase $=0.01$. 
pyroxene within the fractionating assemblage, since olivine-plagioclase fractionation (i.e. $\mathrm{MB} 2$ leading to $\mathrm{MB} 2_{\mathrm{r}}$ ) can only give rise to $\mathrm{Cr}$ enrichment. However, the participation of a small amount of $\mathrm{Cr}$-spinel cannot be excluded as an alternative.

In summary, the evidence points to Lesotho magmas having undergone a period of olivine-clinopyroxene-plagioclase fractionation, followed by a pressure change and some unknown degree of subsequent crystallization to bring the liquids into equilibrium with olivine and plagioclase alone. If this second stage involved significant degrees of fractionation it would have had the effect of producing a cross-trend scatter in the variation diagrams. It is thus interesting to see that the correlation between $\mathrm{MgO}$ and total $\mathrm{Fe}$ as $\mathrm{Fe}_{2} \mathrm{O}_{3}$ for the Lesotho rocks is much better than it is for $\mathrm{CaO}-\mathrm{MgO}$ and $\mathrm{Al}_{2} \mathrm{O}_{3}-\mathrm{MgO}$. Reference to the figures shows that the first of these relationships is likely to be much less sensitive to the operation of the two different fractionation processes than the others are. This provides a hint that some of the scatter in these types of diagrams may be due to polybaric effects within the low pressure regime.

The Rooi Rand dolerites provide the same evidence as the Lesotho lavas. Olivine plus plagioclase is the typical phenocryst assemblage of porphyritic samples, and to date only one sample has been identified as containing clinopyroxene phenocrysts. Yet the evidence of clinopyroxene involvement in the fractionation process is particularly strong and inevitably implies a period of evolution at a pressure higher than that at which the olivine and plagioclase observed were formed (Armstrong, 1978).

The conclusions reached about the Lesotho and Rooi Rand rocks are in agreement with previous work by Thompson $(1972 a, 1972 b)$ on the Snake River Basalts, U.S.A. Thompson found that olivine and plagioclase are on the liquidus at 1 atmosphere pressure and that clinopyroxene always crystallizes at lower temperatures, an experimental conclusion for the Snake River rocks entirely in accord with the petrographic evidence from Lesotho. However, Thompson was forced to postulate the involvement of clinopyroxene fractionation at an early stage in the magmatic history to account for bulk compositional variation in the suite. To confirm this he established that clinopyroxene could be brought on to the liquidus in experiments above $8 \mathrm{~kb}$. Thompson (1972a) develops the general thesis, using evidence from Snake River, from Skye, and from other areas, that intermediate lavas of broadly 'andesitic' type may be generated in the upper mantle. The present work is in very substantial agreement with these ideas except that, because of the apparent involvement of plagioclase in the high-pressure evolutionary stage of the Lesotho and Rooi Rand magmas, it is suggested that the processes involved may take place in the deeper part of the crust rather than in the upper mantle. It is of considerable interest to note that Ewart et al. (in press) have developed an almost identical deep-crustal fractionation model for Tertiary basalts from Queensland although the reasoning is completely different from the arguments presented here.

For completeness it must be recorded that relationships similar to those mentioned above (clinopyroxene involvement despite rareness or absence as a 
phenocryst) are also apparent in the oceanic environment (Dungan \& Rhodes, 1978). These authors explain their 'clinopyroxene paradox' by invoking periodic replenishment of the magma chamber (O'Hara, 1977). In this model liquids which fractionate olivine, clinopyroxene, and plagioclase are repeatedly contaminated by small amounts of less-fractionated liquid so that their 3-phase cotectic nature is disguised while the bulk compositional trend is largely preserved. This is perhaps a valid alternative to the polybaric model adopted here, but the latter is preferred because the continental basalts under study must inevitably have experienced some degree of magmatic evolution under conditions of falling pressure, whereas the role of periodic magma chamber replenishment is at present unknown.

\section{IMPLICATIONS FOR MAGMATIC AND CRUSTAL EVOLUTION}

Proponents of the primary basalt hypothesis find it difficult, as mentioned previously, to point to any significant quantities of mantle having the right compositional characteristics. The converse problem faces any ideas which suppose that basalts are the product of extensive fractional crystallization, that is, where are the alleged cumulates? In this section the latter problem will be discussed on the assumption that parental liquids to flood basalt suites are indeed picritic. The essential question concerns the likelihood or otherwise of picritic magmas being stored below ground in a position where they can plausibly fractionate to give rise to the surface basalts.

\section{The rise of picritic magma}

How magmas rise from the mantle and eventually make their way to the surface, and what the essential controls on this process are, is a very complex problem. Several authors (e.g. Gill, 1973; Goles, 1976; Baker et al., 1978; Elder, 1979a) have discussed mechanisms which, though differing in some fundamental features, assume that lithostatic load and magma density exert a dominating influence on whether magmas will reach the surface or will penetrate upwards only to some equilibrium position below. Generally, high magma density is supposed to inhibit surface eruption.

In the present instance the calculated density of anhydrous model picritic magma (MP) is $2.71 \mathrm{~g} / \mathrm{cm}^{3}$ at $1400^{\circ} \mathrm{C}$ (using the calculation of Bottinga \& Weill, 1970). A natural picrite from the Nuanetsi area (Bezi dyke picrite, $\mathrm{MgO}=$ 18.33 per cent) has a calculated density of $2.78 \mathrm{~g} / \mathrm{cm}^{3}$, and, for comparison, the komatiite $49 \mathrm{~J}$ used for experiments by Green et al. (1975) has a density of $2.79 \mathrm{~g} / \mathrm{cm}^{3}$. It seems unlikely therefore that entirely liquid picritic magmas have densities much in excess of $2.8 \mathrm{~g} / \mathrm{cm}^{3}$. However, it has been argued (Cox, 1978) that picritic magmas might form by the mobilization of their entire source material as crystal-rich porphyritic magmas, and thus at higher levels in the magmatic system at least some crystal content is to be expected. A crystal content of 20 per cent of olivine or orthopyroxene would raise the density to about $2.9 \mathrm{~g} / \mathrm{cm}^{3}$, and values of up to $3.0 \mathrm{~g} / \mathrm{cm}^{3}$ may also not be unrealistic. These estimates coincide with the range for picritic magma used by Baker et al. (1978) in their model for the magmatic evolution of part of the East African rift system and are 
similar to the density assumed by Elder $(1979 a)$ for the high level part of the magmatic system.

Baker et al. imply that picritic 'asthenoliths' rise through the mantle in response to buoyancy forces as operating in a fluid medium and spread out at the base of the crust because their density is intermediate between that of the curst and the mantle. Elder in contrast supposes that magma is transported in fractures and that the level of the top of the magma column is determined principally by the overburden pressure acting in the source region and the density of the magma in the column. The former factor is critically dependent on the thickness of low density crust present, but also dependent on the depth of the source. Both of the above models are likely to be considerable simplifications of the natural system. The present writer finds it difficult to imagine, for example, that large volumes of picritic magma can be emplaced by the Baker et al. mechanism at levels as high as the base of the crust without losing so much heat that they solidify. The process must be envisaged as an exceedingly slow one. Mechanisms such as that discussed by Elder which visualize magmatic transport in at least the upper part of the mantle as controlled by fracturing seem in general more plausible as a means of transporting large quantities of very hot magma to relatively high levels. However, before discussing the Elder model in more detail, it is useful to consider what sort of magma chambers are required by the conclusions reached earlier about the lowpressure regime of basalt crystallization.

\section{Volume of cumulates}

The calculations made already enable us to make rough minimum estimates of the amount of cumulate material to be accounted for. The Lesotho lavas were systematically sampled (Cox \& Hornung, 1966) and it is thus possible to determine an average composition for the lava pile. The average basalt here is produced by about 15 per cent of fractionation (olivine-clinopyroxene-plagioclase) of the most basic type $(\mathrm{MgO}=c a .8$ per cent). The lava pile is $1.5 \mathrm{~km}$ thick and this implies that $0.26 \mathrm{~km}$ of corresponding gabbroic cumulates are concealed below ground. If the parent were 18 per cent $\mathrm{MgO}$ picrite which evolved only by olivine fractionation then a further $0.53 \mathrm{~km}$ of dunite cumulates are also required. These are very distinctly minimum estimates because they depend on the assumption that all available liquids were erupted. For sequences showing greater ranges of variation (e.g. Parana and the Nuanetsi lavas illustrated in Fig. 1) if the average erupted lava corresponds to say 25 per cent crystallization of parental (7 per cent $\mathrm{MgO}$ ) basalt, which itself is formed by $c a$. 25 per cent crystallization of parental (18 per cent $\mathrm{MgO}$ ) picrite, then the minimum volume of concealed cumulates is about the same as that of the surface lavas. From the phase relations it also follows that the gabbroic cumulates at least must have been formed at depths of not more than about $40 \mathrm{~km}$.

\section{Picritic sills}

It is tempting to assume that the missing cumulates are to be found as sill-like bodies at or near the base of the crust, though higher positions are obviously 
possible as witnessed by great intrusions such as the Bushveld complex. The sill form is appealing because it is capable of accommodating large amounts of material without posing a space problem. If only a small fraction of the available fractionated liquid is transmitted to the surface then the amount of material concealed in the magma chamber may be many times larger than the minimum estimates of cumulate volumes derived above. This poses no additional problem if the magma is stored in sub-horizontal tabular chambers.

The sill form has a further advantage in storing magma in a thermal and pressure regime which is comparatively uniform relative to that of any dyke-like body of similar dimensions. For example a deep crustal sill provides the ideal environment for the fractionation of large volumes of magma within a comparatively restricted pressure range, as appears to be demanded by the Lesotho, Rooi Rand, and Snake River data. Unfortunately the factors controlling sill emplacement are poorly understood. Sill emplacement is favoured by a compressional tectonic regime (e.g. Roberts, 1970), by low density country rocks (e.g. Bradley, 1965) and presumably also by structural factors such as horizontal bedding or foliation (Gretener, 1969). It is difficult to be certain which of the last two factors is more important because most of the world's great sill swarms were emplaced in sediments which were both of low density and flat-lying. Probably a combination of both factors, produces the ideal environment.

In southern Africa during the Karroo period there is much evidence of extensional tectonics (Cox, 1970) but it is also a classic area for sills, the Karroo dolerites. It is assumed therefore that there were many periods when dyke emplacement dissipated any deviatoric tensional stress and thus made sill formation possible. Following Elder $(1979 a)$ it is assumed that for a dyke to advance upwards the fluid pressure at the tope of the column must exceed the lithostatic pressure by a factor greater than or equal to the cohesive strength of the rocks. In the case of a picritic magma which has already penetrated into low density crust the cohesive strength of the country rocks must also be exceeded by the fluid pressure at all levels within the crust so that hydraulic fracturing is a likelihood and sill emplacement will take place at lower levels if the structural factors are favourable. Once a sill is established magma supplied from below will feed the sill rather than the dyke, and indeed magma may drain down from the upper part of the dyke to inflate the sill further.

The necessary conditions are obviously fulfilled ideally at high crustal levels within basins filled by young sediments, such as the Karroo basin. It is suggested that conditions may also be suitable at deep crustal levels because of the possibility of widespread sub-horizontal foliation. The density factor is also likely to be favourable at deep crustal levels because it is here that the discrepancy between lithostatic pressure and the pressure in the magma column is maximized (see Elder, 1979a, fig. 3). This may be therefore the most favourable level for hydraulic fracturing of the wall rocks. The ideal position for a picrite sill may thus be somewhere along the crust-mantle boundary or close to it. A single pulse of magma emplaced in this position will differentiate into an upper gabbroic portion and a lower ultramafic layer, thus generating a new seismic Moho at their interface. 
Repeated injection along the new Moho will keep adding gabbro to the crust while generating a new top to the upper mantle by the addition of ultramafic cumulates. Injection at a variety of similar but not identical levels, which may be a more plausible model, will have the effect of producing a Moho which is diffuse, rather than a sharp interface. The definition of what is crust and what is mantle becomes equally diffuse for such a zone. Seismically the presence of plagioclase defines the crust but gabbroic cumulates of a lower sill may underlie ultramafic cumulates of higher sills. The latter, if brought to the surface by liquids emanating from the lower sill will appear to be mantle rocks, and the liquid carrying them will by inference have originated in the mantle. This is a semantic rather than a petrological problem.

\section{The crustal model}

It is assumed that surface lavas will be tapped periodically from the upper part of differentiating sills and will be forced to the surface by lithostatic pressure when the densities of the differentiating liquids drop sufficiently below that of the overlying crust. In many important respects this model is similar to that proposed by Baker et al. (1978) for the southern part of the Kenya rift, though for flood basalt provinces it is regarded as laterally much more extensive. It implies that in areas subject to flood basalt vulcanism there may be a significant addition of gabbroic materials to the base of the crust and a significant addition of ultramafic cumulates to the top of the upper mantle. The total volume of material added in this way is likely to be at least as large as the volume of surface eruptives and may be many times larger. The model also implies that the normal flood basalts seen on the surface are effectively entirely detached from their mantle sources and are fed instead from extensive sill complexes near the crust-mantle boundary (see Fig. 7). It is hardly surprising under these circumstances that such lavas are characteristically devoid of upper mantle xenoliths. Under some favourable circumstances however, picritic liquids can reach the surface directly in zones where crustal thinning has been operative in advance of magmatic activity. This has been proposed by Elder (1979b) for the Tertiary lavas of West Greenland and is in accordance with the tectonic development of the Karroo province as outlined by Cox (1970). The model proposed by Elder turns the surface eruptions off when the lava pile reaches an appropriate height. It may be suggested that at this stage sill development starts at the base of the crust so that vulcanism continues with the eruption of lower density liquids (basaltic as opposed to picritic) once these have been generated in the sill complex. The flood basalt sequences of West Greenland (Clarke, 1970) the Nuanetsi-Lebombo area of the Karroo, and parts of the western Deccan province (Krishnamurthy \& Cox, 1977) all conform to this pattern of early eruptions of picrite giving way to eruptions of normal basalt.

The general features of the model are illustrated in Fig. 7 and there are several direct analogies between the crustal and upper mantle structure here for continental areas subjected to flood basalt vulcanism and models proposed by various authors for the oceanic crust and upper mantle. The essential difference is that in the continental model the pre-existing continental crust separates the surface lavas 


SEDIMENTARY
BONE OF
BASIN
CRUSTAL THINNING

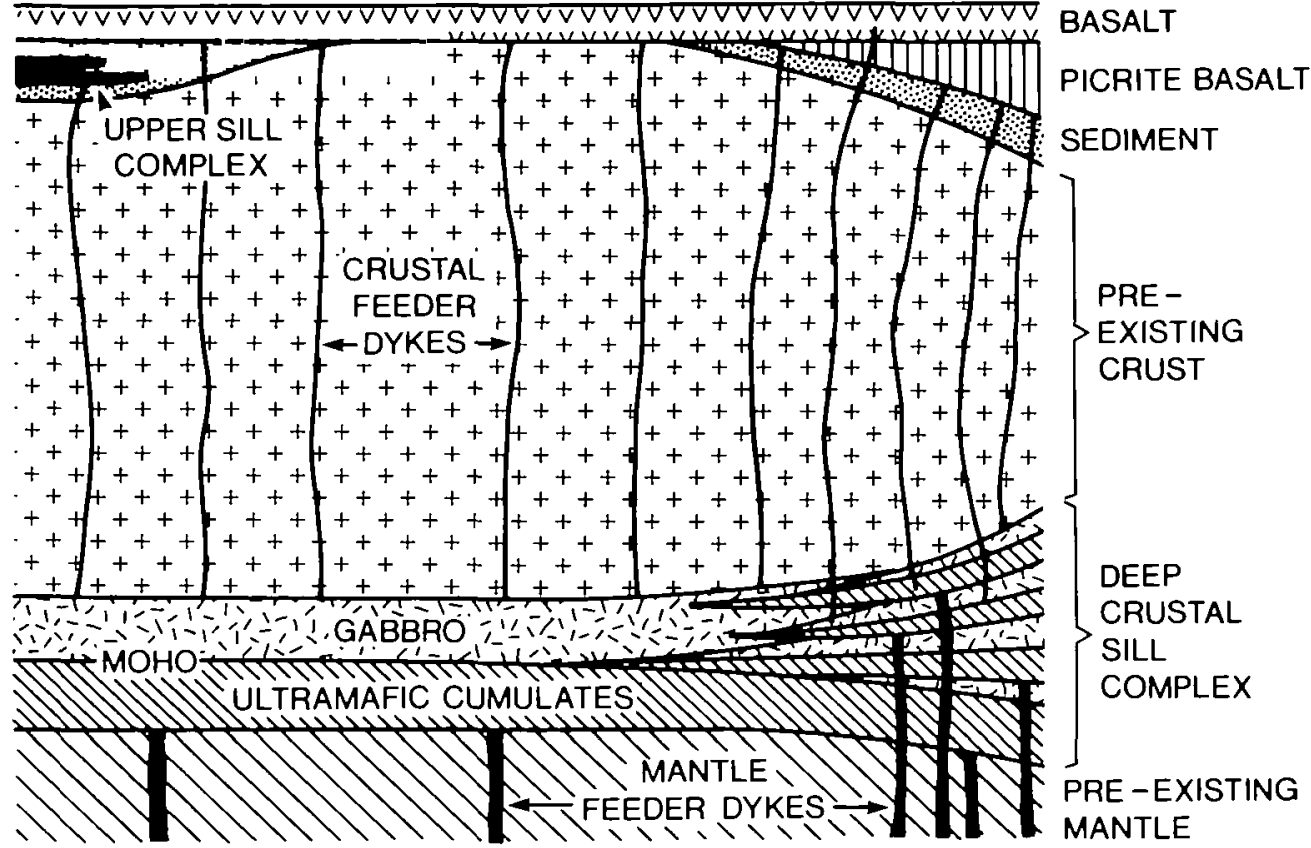

FIG. 7. Model of the continental crust in an area affected by flood vulcanism. The deep crustal sill complex is shown diagrammatically as a single unit (left) generating a sharp Moho and multiple (right) generating a diffuse Moho. The zone of crustal thinning simulates structures such as the Lebombo monocline of the Karroo province, the sedimentary basin represents the Karroo basin. It is not implied that multiple sill injection should be restricted to the crustal thinning zone.

from the cumulate pile, and the sheeted dyke complex of oceanic crust is represented, in the absence of spreading, only by the dyke system which connects the cumulate pile, through the pre-existing crust, to the surface volcanics.

The evidence leading to the proposed model is so far largely circumstantial but an excellent test is in principle available. It is assumed that the deep crustal sill complex is emplaced at a sufficiently high temperature for the initially solidified rocks to exist with a gabbroic mineralogy. However, with the passage of time it is probable that the initial assemblages will invert to granulite facies mineralogy and become a variety of basic garnet-pyroxene-plagioclase-bearing assemblages. Such rocks are found as inclusions in kimberlite in many southern African kimberlite pipes. The pipes post-date the Karroo vulcanism by variable amounts but generally of the order of 100 m.y., and many of them lie within the area subjected to Karroo vulcanism. At the moment relatively little is known about the basic granulites from kimberlite compared with the wealth of data on ultramafic mantle nodules (but see Lovering \& White, 1969; Rogers, 1977; Jackson \& Harte, 1977; Griffin et al., 1977). However, if any of the granulites represent fragments of the former Karroo sill complex they may retain isotopic and other geochemical characteristics which will serve to identify them. They may also despite complete recrystallization retain elements of fabric which may suggest their origin as cumulates. 


\section{ACKNOWLEDGMENTS}

The author is grateful to P. J. Betton, G. M. Biggar, M. J. Norry and J. R. Platt for their helpful comments on an earlier draft of this paper. R. A. Armstrong and J. W. Bristow kindly allowed access to unpublished analytical data for Rooi Rand dolerites.

\section{APPENDIX}

\section{Outline of methods used in calculation of fractionation and equilibrium residual liquid paths}

1. Fractional crystallization. The analysis of the starting material is converted to atomic proportions from which the compositions of the equilibrium olivine, clinopyroxene and plagioclase are calculated using the distribution coefficients of Nathan \& Van Kirk (1978). It is assumed in the present study that $\mathrm{Na}$ does not enter the clinopyroxene in significant amounts so that this phase is calculated only in terms of diopside and hedenbergite end-members. The total weight of the extract to be removed, and the relative weights of the minerals within that extract, are selected at will and the bulk composition of the extract is calculated. This is subtracted from the original analysis and the result recalculated to 100 per cent to give the composition of the residual liquid. The process is repeated as many times as required.

2. Equilibrium crystallization. This calculation depends on choosing initially an arbitrary value for the $\mathrm{Fe} / \mathrm{Mg}$ ratio of the residual liquid, i.e. it calculates the composition of the residual liquid and the degree of crystallization given this $\mathrm{Fe} / \mathrm{Mg}$ value. If it is required to determine the composition of the residual liquid for a given amount of crystallization this must be determined by trial and error.

The given $\mathrm{Fe} / \mathrm{Mg}$ ratio of the residual liquid permits the calculation of the composition of the coexisting olivine and clinopyroxene directly from the distribution coefficients. Knowing the olivine/clinopyroxene ratio (selected arbitrarily at the outset) the bulk composition of the olivine-clinopyroxene mixture can then be calculated. This is subtracted from the original analysis in the correct proportion to give a residue of the correct $\mathrm{Fe} / \mathrm{Mg}$ ratio. This residue represents the ultimate residual liquid plus the plagioclase crystals. The ratio of plagioclase to olivine plus clinopyroxene in the extract is selected arbitrarily so that the amount of plagioclase to be crystallized from the residue is known. There is no option now but to find the plagioclase composition by trial and error, that is, select a plagioclase composition, calculate the residual liquid composition and then see whether the equilibrium plagioclase is the same as the one extracted. Usually three attempts are sufficient to find the right plagioclase within acceptable error limits. The principle of the trial and error calculation depends upon plotting the composition of the plagioclase extracted against the composition of the plagioclase then required by the residual liquid. After two attempts the straight line through the two points intersects the line where the two plagioclase compositions are the same $(i . e . y=x)$ in approximately the correct composition. If the two original choices of plagioclase composition are close together and bracket the correct value, the composition so 
found is not significantly in error. To the author's knowledge there is no exact solution to this type of calculation but the procedure outlined above is well suited to computer application.

\section{REFERENCES}

Armstrong, R. A., 1978. A geological and geochemical appraisal of the Rooi Rand dyke swarm, Lebombo. M.Sc. thesis, University of Natal, Durban.

Baker, B. H., Crossley, R., \& Goles, G. G., 1978. Tectonic and magmatic evolution of the southern part of the Kenya rift valley. In Neumann, E. R. \& Ramberg, I. B. (Eds.), Petrology and geochemistry of continental rifts. Dordrecht, Holland: D. Reidel Publishing Company, 29-50.

BotTingA, Y, \& WeILL, D. F., 1970. Densities of liquid silicate systems calculated from partial molar volumes of oxide components. Am. J. Sci. 269, 169-82.

Bradley, J., 1965. The intrusion of major dolerite sills. Trans. R. Soc. N.Z. 3, 27-55.

Carmichael, I. S. E., Turner, F. J. \& Verhoogen, J., 1974. Igneous Petrology. New York: McGraw-Hill Book Company.

Clarke, D. B., 1970. Tertiary basalts from Baffin Bay: possible primary magma from the mantle. Contr. Miner. Petrol. 25, 203-24.

Cox, K. G., 1970. Tectonics and vulcanism of the Karroo period and their bearing on the postulated fragmentation of Gondwanaland. In Clifford, T. N. \& GASS, I. G., (Eds.) African magmatism and tectonism. Edinburgh: Oliver \& Boyd, 211-36.

1972. The Karroo volcanic cycle. J. geol. Soc. Lond. 128, 311-36.

1978. Komatiites and other high-magnesia lavas: some problems. Phil. Trans. R. Soc. Lond. A288, 599-609.

—- Bell, J. D., \& Pankhurst, R. J., 1979. The interpretation of igneous rocks. London: George Allen \& Unwin.

\& Hornung, G., 1966. The petrology of the Kartoo basalts of Basutoland. Am. Miner. 51, 1414-32. \& JAmieson, B. G., 1974. The olivine-rich lavas of Nuanetsi: a study of polybaric magmatic evolution. J. Petrology, 15, 269-301.

- Johnson, R. L., Monkman, L. J., Stillman, C. J., Vail, J. R., \& Wood, D. N., 1965. The geology of the Nuanetsi igneous province. Phil. Trans. R. Sac. Lond. A257, 71-218.

Dungan, M. A., \& Rhodes, J. M., 1978. Residual glasses and melt inclusions in basalts from DSDP Legs 45 and 46: evidence for magma mixing. Contr. Miner. Petrol. 67, 417-31.

Elder, J. W., 1979a. Magma traps: Part I, Theory. In: RyBACH, L, \& StegenA, L. (Eds.) Geothermics and geothermal energy. Contributions to current research in geophysics, 7, 3-14.

1979b. Magma traps: Part II, Application. ibid., 7, 15-33.

Ewart, A, Baxter, K., \& Ross, J. A., (in press). The Tertiary anorogenic lavas of southern and central Queensland, Australia - mineralogy, chemistry and petrogenesis. Contr. Miner. Petrol.

GILL, R. C. O., 1973. Mechanism for the salic magma bias of continental alkaline provinces. Nature phys. Sci. 242, 41-2.

Goles, G. G., 1976. Some constraints on the origin of phonolites from the Gregory Rift, Kenya, and inferences concerning basaltic magmas in the rift system. Lithos, 9, 1-8.

GREEN, D. H., 1973. Experimental melting studies on a model upper mantle composition at high pressure under water saturated and water under-saturated conditions. Earth planet. Sci. Lett. 19, 37-53.

— Nicholls, I. A., Viljoen, M., \& Vinjoen, R., 1975. Experimental demonstration of the existence of peridotitic liquids in earliest Archean magmatism. Geology, 3, 11-14.

Gretener, P. E., 1969. On the mechanics of the intrusion of sills. Can. J. Earth Sci. 6, 1415-19.

Griffin, W. L., Carswell, D. A., \& Nixon, P. H., 1977. Lower crustal granulites and eclogites from Lesotho and South Africa. Second International Kimberlite Conference, Santa Fe, Extended Abstracts Volume.

GURNEY, J. J., \& HARTE, B., (in press). Chemical variations in upper mantle nodules from southern African kimberlites. Phil. Trans. R. Soc. Lond.

Hart, S. R., \& DAvis, K. E., 1978. Nickel partitioning between olivine and silicate melt. Earth planet. Sci. Lett. 40, 203-19.

JACKSON, P. M., \& HARTE, B., 1977. The nature and conditions of formation of granulite facies xenoliths from the Matsoku kimberlite pipe, Lesotho. Second International Kimberlite Conference, Santa Fe, Extended Abstracts Volume.

Krishnamurthy, P., \& Cox, K. G., 1977. Picrite basalts and related lavas from the Deccan Traps of western India. Contr. Miner. Petrol. 62, 53-75.

Kushiro, I., 1972. Effect of water on the composition of magmas formed at high pressures. J. Petrology, $13,311-34$.

Lovering, J. F. \& WhITE, A. J. R., 1969. Granulitic and eclogitic inclusions from basic pipes at Delegate, Austratia. Contr. Miner. Petrol. 21, 9-52. 
MySEN, B., \& BOETTCHer, A. L., 1975. Melting of a hydrous mantle: II. Geochemistry of crystals and liquids formed by anatexis of mantle peridotite at high pressures and high temperatures as a function of controlled activities of water, hydrogen, and carbon dioxide. J. Petrology, 16, 549-93.

NATHAN, H. D., \& V AN KiRK, C. K., 1978. A model of magmatic crystallization. lbid., 19, 66-94.

Nicholls, I. A., \& RINGwOOD, A. E., 1973. Effect of water on olivine stability in tholeiites and the production of silica-saturated magmas in the island-arc environment. J. Geol. 81, 285-300.

O'HARA, M. J., 1965. Primary magmas and the origin of basalts. Scott. J. Geol. 1, 19-40. 1968a. Are ocean floor basalts primary magma? Nature, 220, 683-6.

1968b. The bearing of phase equilibria studies in synthetic and natural systems on the origin and evolution of basic and ultrabasic rocks. Earth Sci. Rev. 4, 69-133.

1977. Geochemical evolution during fractional crystallization of a periodically refilled magma chamber. Nature, 266, 503-7.

PeARCE, T. H., 1978. Olivine fractionation equations for basaltic and ultrabasic liquids. ibid., 276, 771-4.

Presnall, D. C., Dixon, J. R., O'Donnell, T. H., \& Dixon, S. A., 1979. Generation of mid-ocean ridge tholeiites. J. Petrology, 20, 3-35.

RiCHARDSON, S. H., 1979. Chemical variation induced by flow differentiation in an extensive Karroo dolerite sheet, southern Namibia. Geochim. cosmochim. Acta, 43, 1433-41.

Roberts, J. L., 1970. The intrusion of magma into brittle rocks. In: Newall, G., \& Rast, N., (Eds.), Mechanisms of igneous intrusion. Geol. J. Special Issue 2, 287-338.

Roeder, P. L., \& Emslete, R. F., 1970. Olivine-liquid equilibria. Contr. Miner. Petrol. 29, $275-89$.

RoGers, N. W., 1977. Granulite xenoliths from Lesotho kimberlites and the lower continental crust. Nature, 270, 681-4.

RÚegG, N. R. \& A maral, G., 1976. Variação regional da composição quimica das rochas basálticas da bacia do Paraná. Bol. IG. Univ. São Paulo, 7, 131-47.

Thompson, R. N., 1972a. Evidence for a chemical discontinuity near the basalt-andesite transition in many anorogenic volcanic suites. Nature, 236, 106-10. 1972b. The 1-atmosphere melting patterns of some basaltic volcanic series. Am. J. Scl. 272, 901-32.

Tuttle, O. F., \& Bowen, N. L., 1958. Origin of granite in the light of experimental studies in the system $\mathrm{NaAlSi}_{3} \mathrm{O}_{2}-\mathrm{KALSi}_{3} \mathrm{O}_{2}-\mathrm{SiO}_{2}-\mathrm{H}_{2} \mathrm{O}$. Mem. geol. Soc. Am. 74.

WILKINSON, J. F. G., \& BINNS, R. A., 1977. Relatively iron-rich lherzolite xenoliths of the Cr-diopside suite: a guide to the primary nature of anorogenic tholeiitic andesite magmas. Contr. Miner. Petrol. 65, 199-212.

WooD, D. A., 1978. Major and trace element variations in the Tertiary lavas of eastern Iceland and their significance with respect to the Iceland geochemical anomaly. J. Petrology, 19, 393-436. 